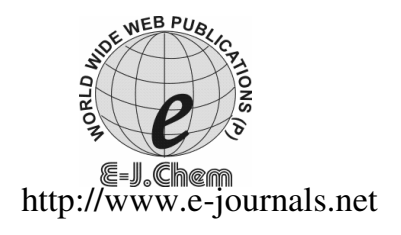

\title{
Hydrogeochemistry of the Paravanar River Sub-Basin, Cuddalore District, Tamilnadu, India
}

\author{
K.SHANKAR, S.ARAVINDAN and S.RAJENDRAN \\ Department of Earth Sciences \\ Annamalai University, Annamalai Nagar - 608 002, India \\ geoshankar1984@gmail.com
}

Received 10 July 2010; Accepted 3 September 2010

\begin{abstract}
To assess the groundwater quality of the Paravanar river basin, groundwater data were collected by conventional methods. Hydrogeochemical facies of groundwater of study area reveals fresh to brackish and alkaline in nature. Piper plot shows that most of the groundwater samples fall in the mixed field of $\mathrm{Ca}-\mathrm{Mg}-\mathrm{Cl}$ type. Using GIS mapping technique, major element concentration of groundwater has been interpolated and studied. Groundwater thematic maps on electrical conductivity (EC), hydrogen ion concentration, bicarbonates, chlorides and nitrates were prepared from the groundwater quality data. Different classes in thematic maps were categorized as i) good, ii) moderate and iii) poor with respect to groundwater quality. Northeast and southeast parts of the study area represent the doubtful water class regarding the concentration of EC to represent connate nature of water adjacent to the coast. NNE (North-NorthEast) and southern parts of the study area have $\mathrm{pH}$ ranging from 7 to 8 indicating acidic nature as they were from the weathered Cuddalore sandstone. As northern part of the study area is irrigated, fertilizer used for agriculture may be the source for increase in concentration of nitrates. Chloride clusters in the south central part of the study area from coast up to NLC mines and reveals the chloridization of aquifer in 48 years either due to upwelling of connate water from the deeper aquifer as a result of depressurization of Neyveli aquifer for the safe mining of lignite.
\end{abstract}

Keywords: Paravanar, Tamilnadu, Groundwater quality, Hydrogeochemisty.

\section{Introduction}

Groundwater is an excellent solvent that dissolves chemical ions, as it moves through rocks and subsurface soil. This leads to more mineralization in groundwater than surface water. Earth surface is acting as an effective filtrate to filter out particulate matters like leaves, soils, bugs, dissolved chemicals and gases. Above matters also occur in large concentrations to change the physicochemical properties of groundwater. To understand the above process, hydrogeochemical studies were attempted in the Paravanar basin in Tamilnadu to monitor the concentration of various major and minor constituents present in groundwater. 


\section{Experimental}

To achieve the above objectives, various data generated in the field were converted into information in the lab. (Table 1).

The conventional techniques of histograms and trilinear techniques ${ }^{1}$ such as Stiff and Piper plots which consider only the major and minor ions with equal emphasis to interpret the group of variables to evaluate the chemical nature of groundwater has several limitations. In order to overcome these limitations of these conventional methods, factor analytical technique has been used to understand a number of geochemical processes by several professionals ${ }^{2-9}$.

GIS is an effective tool for storing large volumes of data that can be correlated spatially and retrieved for the spatial analysis and integration to produce the desirable output. GIS has been used by scientists of various disciplines for spatial queries, analysis and integration for the last three decades ${ }^{10}$. A number of studies were conducted to determine potential sites for groundwater exploration in diverse geological set ups using remote sensing and GIS technique ${ }^{11-13 .}$

Geographic information system (GIS) is an efficient and effective tool in solving problems where spatial data are important. Therefore, it is widely used for assessment of water quality and developing solutions for water resources related problems ${ }^{14}$. GIS based spatial distribution mapping and suitability evaluation of groundwater quality for domestic and agricultural purpose $^{15}$. Geographical information system (GIS) to represent and understand the spatial variation of various geochemical elements in Panvel Basin, Maharashtra and India ${ }^{16}$. Therefore, groundwater quality plays a major role in planning water supply, water quality management, public health management and environmental management.

\section{Study area}

The study area (Figure 1) of the Paravanar sub-basin lies in the Cuddalore District. It is bounded on the north by the main Gadilam river basin, on the south by the Vellar basin, on the east by Bay of Bengal.

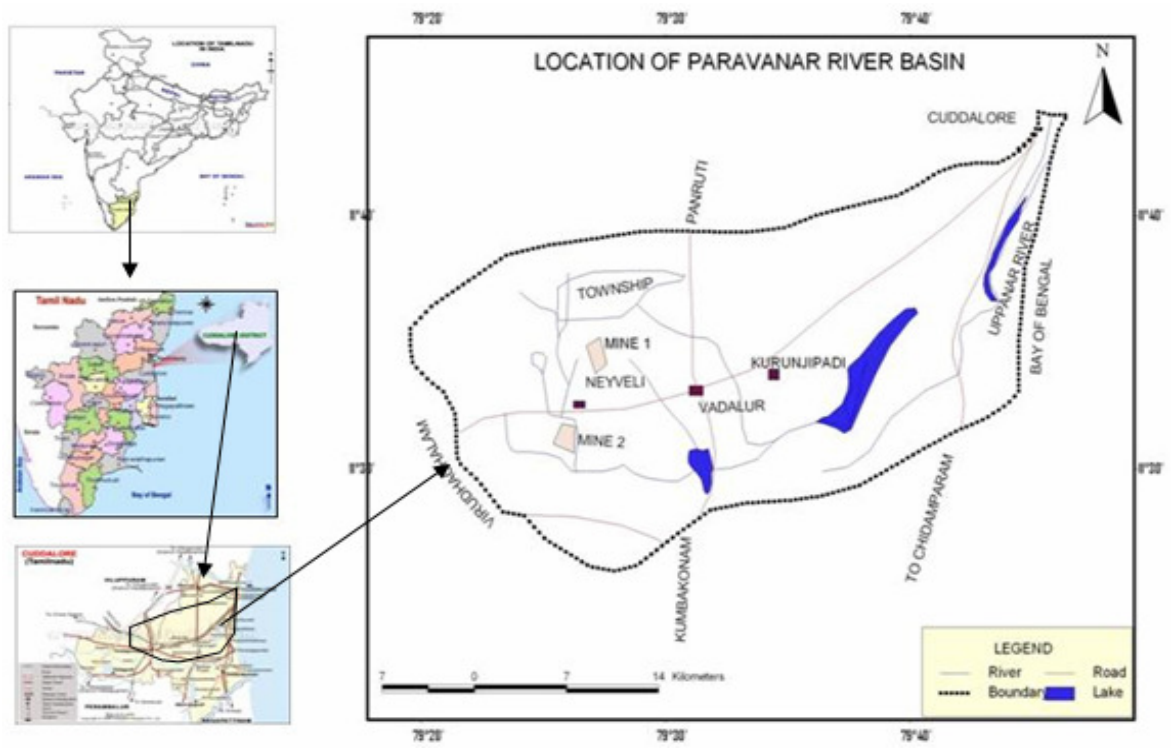

Figure 1. Location map of the study area 
Most part of the study area is a flat plain, slopping very gently towards the sea on the east. The uplands are only on the northwestern border, with the capper mound or the red plateau running parallel to the sea with an elevation of $<25$ meters above M.S.L., forming part of red lateritic "Cuddalore sand stones". The area has a tropical climate with the highest and lowest temperatures recorded in May and January respectively. The precipitation of this study area mainly depends upon north east monsoon, which is cyclonic in nature and attributed to the development of low pressure in the Indian Ocean and Bay of Bengal. This area receives about an annual rainfall of $1,162 \mathrm{~mm}$. The study area includes two very large (Mines I and II) and one small (Mine IA) opencast lignite mines, associated industries (two pit-head thermal power plants, a urea plant, and a briquetting and carbonization plant) that are operated by Neyveli Lignite Corporation Ltd. (NLC) and an independent power plant.

The study area is underlined by geological formations, ranging in age from the Tertiary to recent alluvium sediments (Figure 2). As geological structures control the occurrence and movement of groundwater, the geological map of the study area was checked with field investigations and with the help of geological map of the Cuddalore District, which was published by Geological Survey of India (2001). The River Paravanar originates from the Cuddalore sandstone of Tertiary age. This formation is completely composed of mottled argillaceous sandstone ${ }^{17}$. The Cuddalore sandstone occurs at capper plateau south of Cuddalore town and is made up of sandstone, clay and silt. The lower Cuddalore sandstone is unconsolidated at few places. The sandstones are found intercalated with clay lenses and covered by lateritic formation ${ }^{18}$. The major soil types found in this basin are Inceptisol, Entisol, Alfisol and Vertisol.

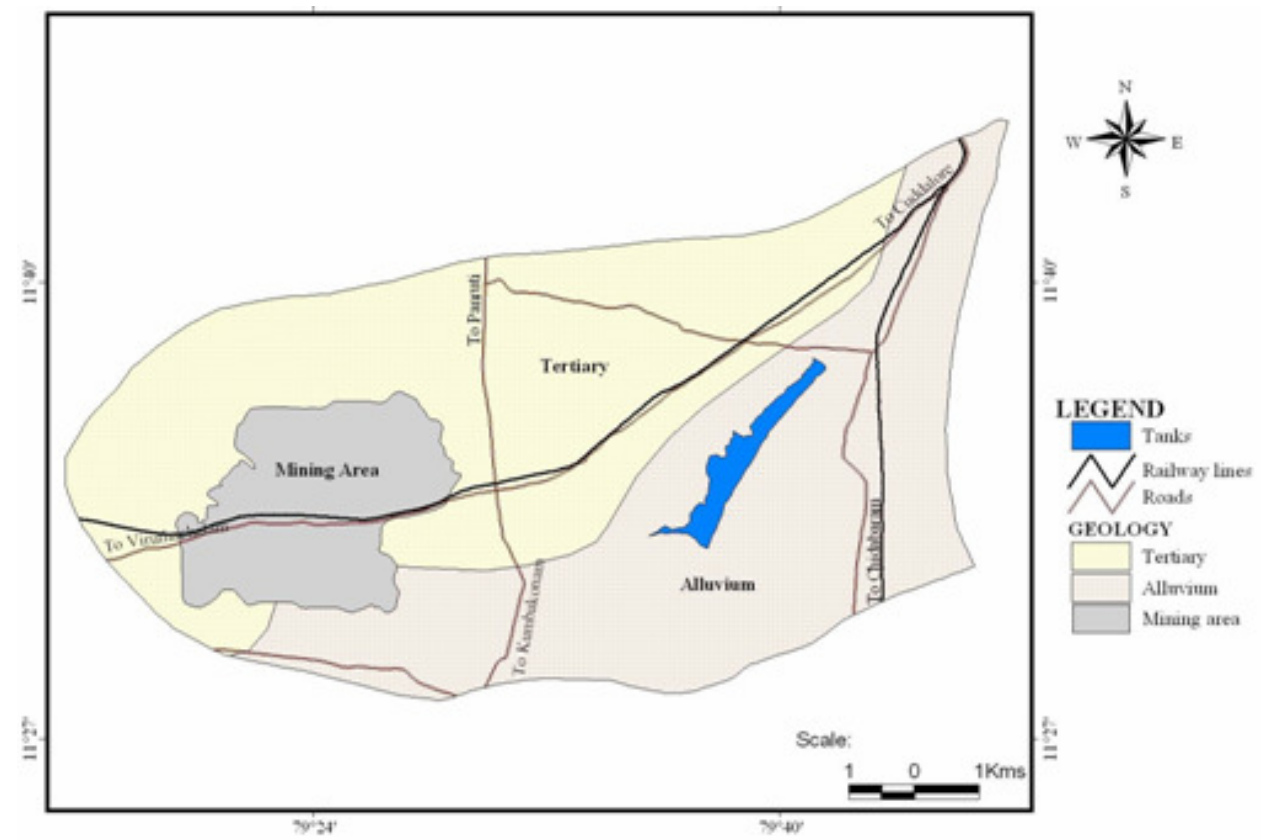

Figure 2. The geology of study area

The present work was attempted to evaluate the groundwater quality and its suitability for domestic, irrigation and industrial purposes of Paravanar River basin, by generating and amalgamating the groundwater quality data of Paravanar River sub basin. 17 Wells were selected 
for this study (Figure 3) and these wells are widespread in the study area. Groundwater was sampled (Table.1) in the month of June 2007. Water samples were collected mostly from observation wells of PWD.

Table 1. Hydrogeochemical data (Post monsoon of 2007)

\begin{tabular}{ccccccccccccc}
\hline S.No. & Location & $\mathrm{EC}$ & $\mathrm{pH}$ & $\mathrm{Ca}$ & $\mathrm{Mg}$ & $\mathrm{Na}+\mathrm{K}$ & $\mathrm{HCO}_{3}$ & $\mathrm{CO}_{3}$ & $\mathrm{SO}_{4}$ & $\mathrm{Cl}$ & $\mathrm{NO}_{3}$ & $\mathrm{TDS}$ \\
\hline 1 & Annadanapettai & 360 & 8.3 & 24 & 0.2 & 23 & 73 & 12 & 14 & 36 & 6.12 & 196.7 \\
2 & Meenakshipettai & 1860 & 8.6 & 40 & 2 & 222 & 153 & 15 & 29 & 527 & 12 & 1008.6 \\
3 & Kullanchavadi & 760 & 8.3 & 20 & 0.5 & 0.5 & 134 & 12 & 48 & 149 & 6 & 471.8 \\
4 & Puliyur & 580 & 7.7 & 28 & 1.3 & 54 & 116 & 0 & 53 & 114 & 0 & 374 \\
5 & Sathankuppam & 570 & 7.7 & 26 & 0.6 & 58 & 128 & 0 & 4.8 & 114 & 25 & 364.1 \\
6 & Ramapuram & 503 & 7.2 & 14 & 1.2 & 62 & 67 & 0 & 62 & 110 & 31 & 354.4 \\
7 & Vallichothanaipalayam & 1080 & 8.2 & 38 & 0.12 & 200 & 244 & 42 & 38 & 320 & 37 & 927.3 \\
8 & Kanarapettai & 870 & 8.3 & 76 & 28 & 60 & 183 & 12 & 115 & 106 & 6 & 594.3 \\
9 & Vadalur & 480 & 8.4 & 24 & 0.9 & 46 & 116 & 6 & 10 & 71 & 50 & 332.3 \\
10 & Abaddhapuram & 300 & 8.4 & 30 & 1 & 17 & 123 & 6 & 0 & 28 & 0 & 213.4 \\
11 & Jubleeclub & 2580 & 8.1 & 28 & 2.4 & 253 & 187 & 72 & 250 & 178 & 62 & 1042.5 \\
12 & Alapakkam & 2176 & 8.39 & 52 & 3.3 & 187 & 287 & 57 & 53 & 374 & 0.4 & 1022 \\
13 & Marungur & 230 & 7.8 & 10.02 & 40.86 & 32.18 & 16.5 & 0 & 40.8 & 38.99 & 0 & 129 \\
14 & Muthandikuppam & 160 & 7.9 & 8.02 & 4.86 & 19.59 & 73.2 & 0 & 17.72 & 20.65 & 9.3 & 88 \\
15 & Maruvai & 451 & 7.74 & 16 & 8.2 & 17.1 & 42 & 0 & 29 & 34 & 26 & 316 \\
16 & Sorathur & 230 & 7.9 & 24.05 & 9.75 & 6.89 & 95.52 & 0 & 1 & 14.18 & 25.63 & 126 \\
17 & perpriyankuppam & 700 & 8.3 & 18.04 & 21.88 & 98.85 & 170.84 & 30 & 28.22 & 77.98 & 120.2 & 370 \\
\hline \multicolumn{7}{c}{} & & & & & &
\end{tabular}

(All the parameters in $\mathrm{mg} / \mathrm{L}$, except $\mathrm{pH} ; \mathrm{EC}=\mu \mathrm{S} / \mathrm{cm}$ )

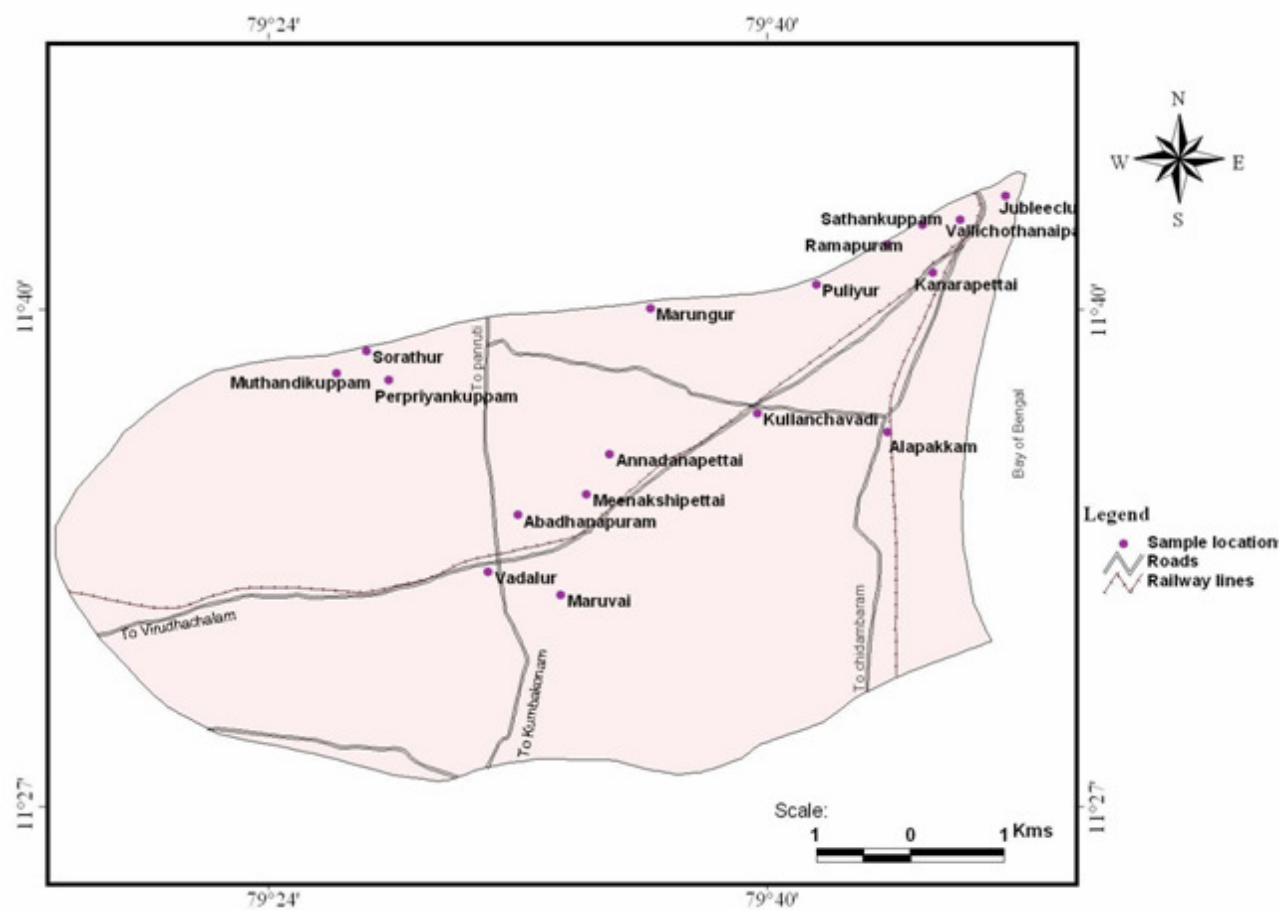

Figure 3. Well location map in the study area 
The water samples were collected in $500 \mathrm{~mL}$ polyethylene bottles. Before collection sampled bottles were soaked with $1: 1 \mathrm{HNO}_{3}$, washed using a detergent and rinsed using double distilled water. At the time of sampling, the sampling bottles were thoroughly rinsed two or three times using the groundwater to be sampled.

The hydrogeochemical characteristics of water and its portability were obtained through physiochemical recordings like Temperature, Electrical Conductivity (EC) and hydrogen-ion concentration $(\mathrm{pH})$ using in situ portable meters. Samples were tightly packed and transported to the laboratory for chemical analysis on the same day. The $\mathrm{pH}$ readings were taken using a $\mathrm{pH}$ meter. The $\mathrm{pH}$ electrode was calibrated using 2 buffer solutions ( $\mathrm{pH} 7$ and $\mathrm{pH} 10$ ). Since there was automatic temperature compensation probe, the readings was recalculated considering the temperature of water during collection as $25{ }^{\circ} \mathrm{C}$. EC, salinity and Total Dissolved Solids (TDS) were measured using a precalibrated portable meter. Readings were taken for the above parameters at each 17 sites.

The collected groundwater samples were filtered and acidified with nitric acid for analysis. The samples were analyzed for concentrations of major elements like bicarbonate $\left(\mathrm{HCO}_{3}\right)$ and chloride $\left(\mathrm{Cl}_{2}\right)$ ions. The analytical procedures used were adopted from APHA ${ }^{19}$. During the analyses, blanks and standards were run to check the reliability of the methods adopted. After completion of the analysis of major ions, the ionic balance error was calculated. In general, ion balance error was within $10 \%$. The collected groundwater samples were analyzed for major ions by following the standard analytical methods and the accuracy of chemical analyses were checked as per the procedure listed $b^{20}$.

\section{Results and Discussion}

\section{Electrical conductivity}

Electrical conductivity (EC) is a measure of the total salt content of water based on the flow of electrical current through the sample. The higher the salt content, greater will be the flow of electrical current. Measured EC values range from 160 to 2580 microsiemens $/ \mathrm{cm}$. The highest value of $2580 \mathrm{microsiemens} / \mathrm{cm}$ was found in the sample near the coast (Figure 4). NE and SE (adjacent to SIPCOT industrial complex) part of the study area represents the doubtful water class regarding the concentration of EC to represent the connate nature of water adjacent to the coast to indicate the increasing age (Table 2).

Table 2. Quality of groundwater based on electrical conductivity

\begin{tabular}{cccc}
\hline EC $($ micro mhos/cm) & Water class & Representing wells & $\begin{array}{c}\text { Total no. } \\
\text { of wells }\end{array}$ \\
\hline$<250$ & Excellent & 13,14 and 16 (Sorathur) & 3 \\
$250-750$ & Good & $1,4,5,6,9,10,15 \& 17$ & 8 \\
$750-2000$ & Permissible & $2,3,7 \& 8$ (Kanarapettai) & 4 \\
$2000-3000$ & Doubtful & $11 \& 12$ (Alapakkam) & 2 \\
$>3000$ & Unsuitable & Nil & Nil \\
\hline
\end{tabular}

\section{Hydrogen ion concentration ( $\mathrm{pH}$ )}

Most groundwater found in the Paravanar river sub basin has $\mathrm{pH}$ value ranging from about 7.2 to 8.6. The regional distribution of groundwater $\mathrm{pH}$ is given in Figure 5. Central and southern part of the study area has high $\mathrm{pH}$ value, which may be due to industrial and mining activity, along with lateralized sandstone as a host rock. Rest of the area is found to be alkaline in nature (Figure 5). 


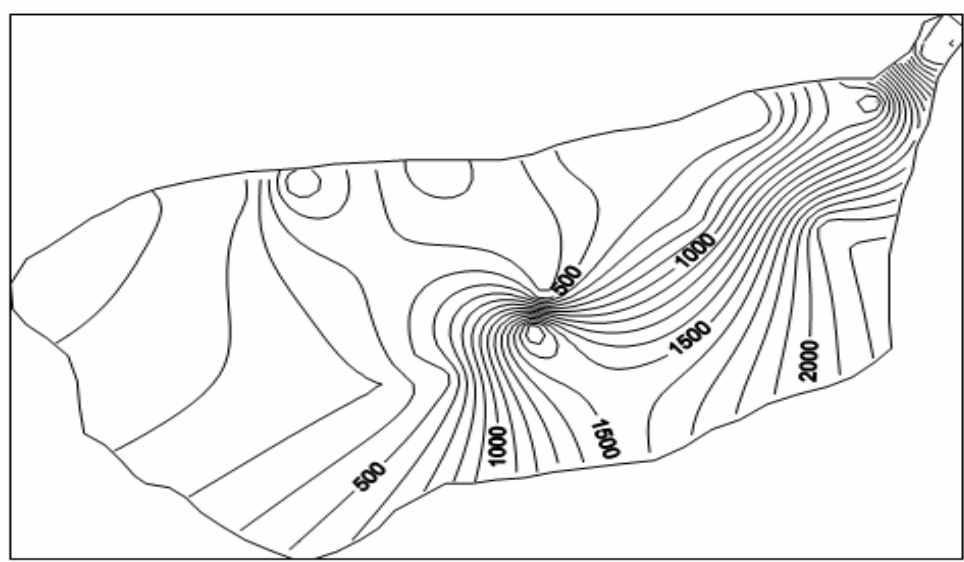

Figure 4. Spatial variation of EC values

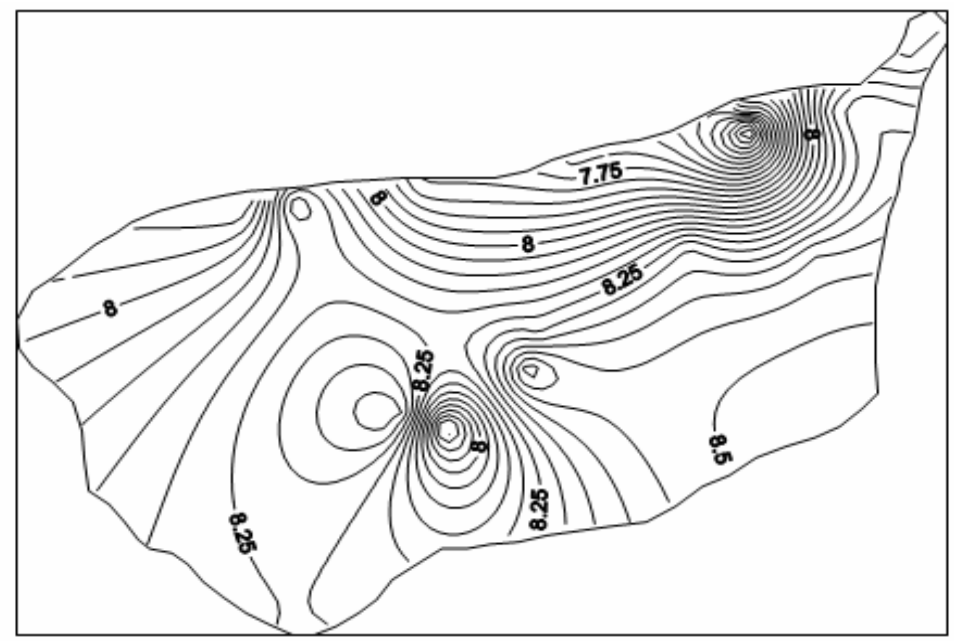

Figure 5. Seasonal variation of $\mathrm{pH}$ values

\section{Stiff diagram}

Pattern diagrams, first suggested by Stiff $^{21}$, for representing chemical analyses by four parallel axes, are illustrated in Figure 6. Concentrations of cations were plotted to the left of a vertical zero axis and anions to the right, all values are in milliequivalents per liter. The resulting points, when connected, form an irregular polygonal pattern; water of a similar quality defines a distinctive shape. The Stiff plots for groundwater illustrate that there are two end-members, representing water dominated by sodium-potassium and bicarbonate-carbonate and water with low TDS. The STIFF plots for the remaining samples appear to fall somewhere between these two end-members and may represent a mixing of the two waters.

The plot shows that most of the groundwater samples analysed during July 2007 fall in the field of mixed $\mathrm{Ca}-\mathrm{Mg}-\mathrm{Cl}$ type of water (Figure 7). Some samples are also representing $\mathrm{Ca}-\mathrm{Cl}$ and $\mathrm{Na}-\mathrm{Cl}$ types. From the plot, alkaline earths $\left(\mathrm{Ca}^{2+}\right.$ and $\left.\mathrm{Mg}^{2+}\right)$ significantly exceed the alkalis $\left(\mathrm{Na}^{+}\right.$and $\left.\mathrm{K}^{+}\right)$and strong acids $(\mathrm{Cl})$ and $\left(\mathrm{SO}_{4}\right)$ exceed the weak acids $\left(\mathrm{HCO}_{3}\right)$ and $\left(\mathrm{CO}_{3}\right)$. 


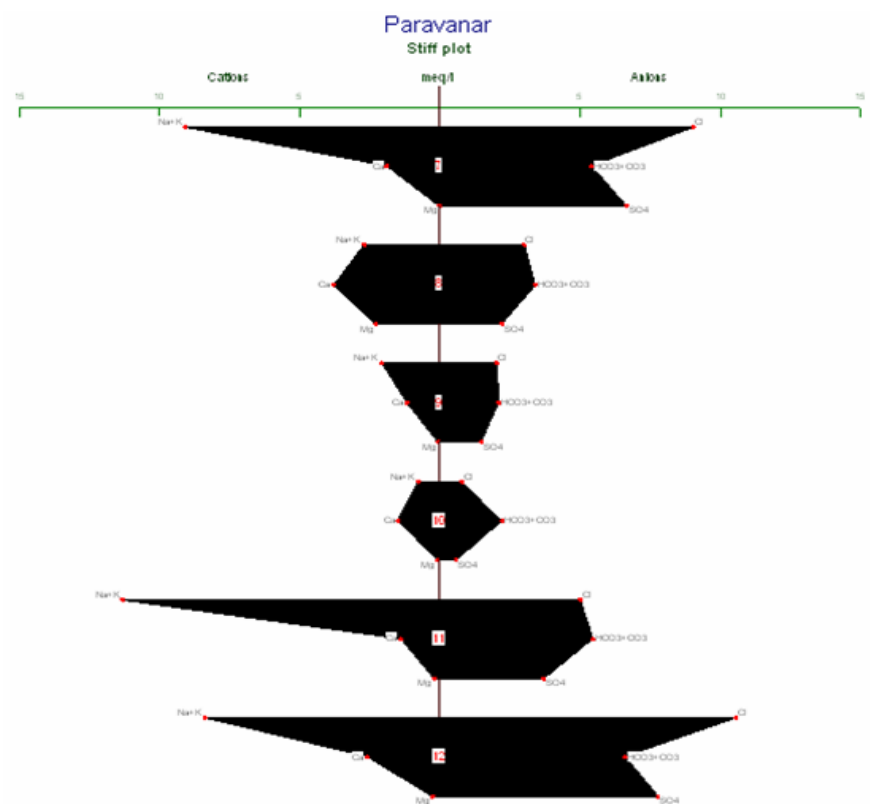

Figure 6. Chemical parameters in Stiff Plot

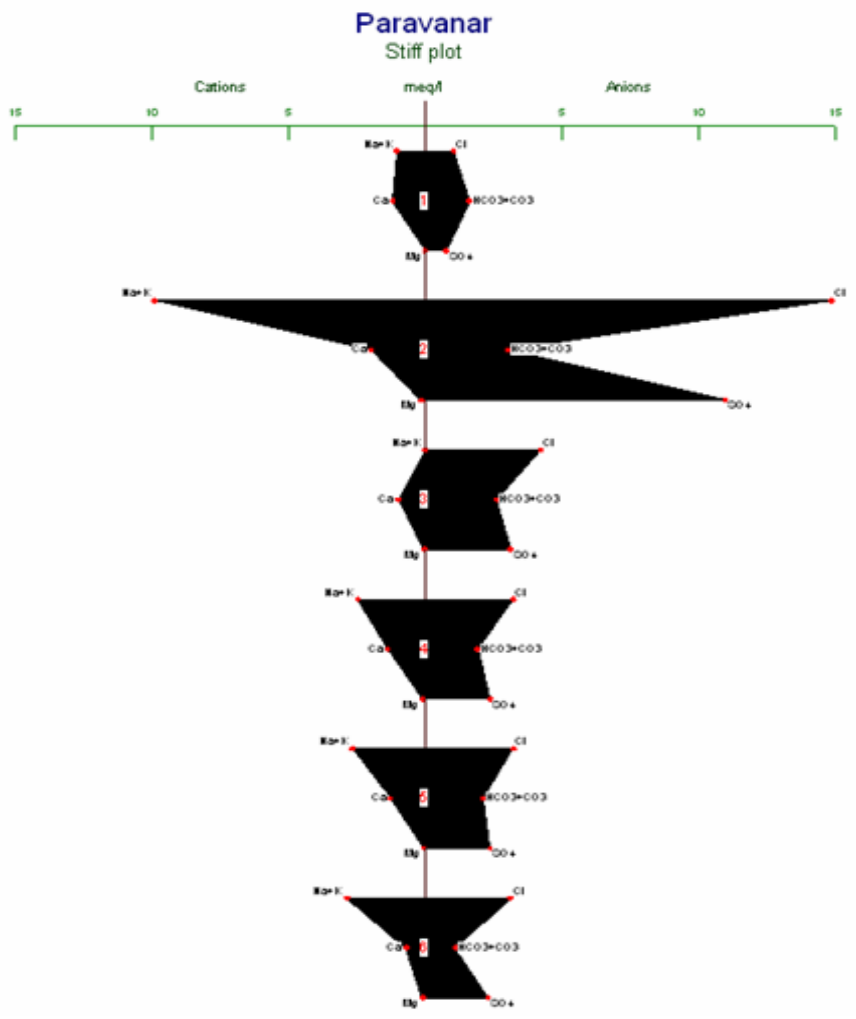

Figure 7. Chemical parameters in Stiff Plot 


\section{Bicarbonate}

The primary source of bicarbonate ions in groundwater is the dissolved $\mathrm{CO}_{2}$ in rain water that on entering in the soil dissolves more carbon dioxide. An increase in temperature or decrease in pressure causes reduction in the solubility of $\mathrm{CO}_{2}$ in water decay of organic matter and $\mathrm{SO}_{4}$ reducing bacteria may also release $\mathrm{CO}_{2}$ for dissolution. Water charged with $\mathrm{CO}_{2}$ dissolved carbonate minerals, passes through soil and rocks, to give bicarbonates. Weathering of silicate mineral also has the possibility of bicarbonate liberation. $\mathrm{HCO}_{3}$ concentration is classified based on WHO's standard ${ }^{22}$, with $<100 \mathrm{ppm}$ is categorized as poor zone, which is suitable only for industrial activity (Table 3).

Table 3. Suitability of drinking quality of bicarbonate ions

\begin{tabular}{cc}
\hline Concentration of $\mathrm{HCO}_{3}$ in ppm & Suitable zone \\
\hline$<100$ & Poor \\
$100-250$ & Moderate \\
$>250$ & Good \\
\hline
\end{tabular}

Northern and southern parts of the study area (Figure 8) represent minimum amount of hardness to neutralize acids, hence above part is categorized as poor zone. Moderate zone is found to occur in northwest, southwest and in central part of the study area by considering the concentration of $<250 \mathrm{ppm}$ (Figure 8). Good zone is found to occur in east and south eastern parts of the study area as the concentration is $>250 \mathrm{ppm}$.

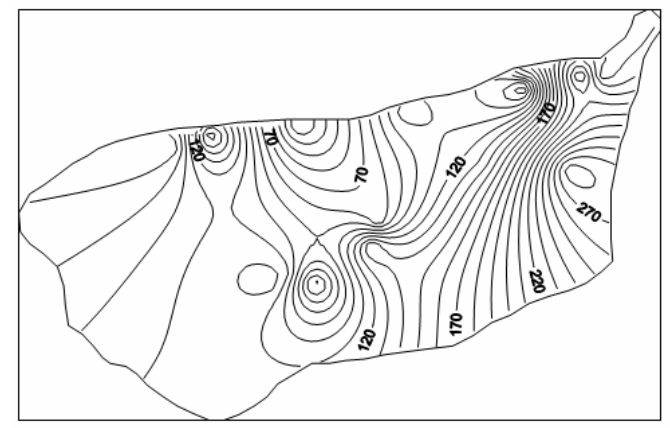

Figure 8. Seasonal variations of $\mathrm{HCO}_{3}$ ions

\section{Chloride}

The chloride ion occurs in natural water in fairly low concentration, usually $<100 \mathrm{mg} / \mathrm{L}$ unless the water is brackish or saline. Chloride is used by human beings in many applications and can be added to the subsurface via industrial discharges, sewage, animal wastes and road salting. The chloride ions are not absorbed into the mineral or organic surface and do not form insoluble precipitates. Chloride-bearing minerals such as sodalite and chloro-apatite, which form very minor constituents of igneous, metamorphic rocks and liquid inclusions comprises very insignificant fraction of the rock volume and form as minor sources of chloride in ground water. The distribution of chloride ion concentration individually reflects the water interaction with rocks, permeability variations of aquifer and inters transmissivity of rock ${ }^{23,24}$.

Based on ISI standard, chloride concentration is classified $<100 \mathrm{ppm}$ as good zone suitable for drinking. Moderate ground water suitable zone is categorized under the class of 100 - $250 \mathrm{ppm}$ (Table 4). Above $250 \mathrm{ppm}$ zones were classified as poor ground water suitable zones. The chloride ion concentration in the study area varies between $28 \mathrm{mg} / \mathrm{L}$ and $527 \mathrm{mg} / \mathrm{L}$. The spatial distribution of chloride concentration in groundwater of the study area 
is illustrated in the Figure 9. Meenakchipettai, Vallichothani Palayam and Allapakkam represent the maximum $\mathrm{Cl}_{2}$ concentration of 527, 320 and $374 \mathrm{ppm}$ respectively which is more than ISI standard of $250 \mathrm{ppm}$ for drinking.

Table 4. Suitability of drinking quality of chloride ions

\begin{tabular}{cc}
\hline Concentration of chloride in ppm & Suitable Zone \\
\hline$<100$ & Good \\
$100-250$ & Moderate \\
$>250$ & Poor \\
\hline
\end{tabular}

Eastern part of study area adjacent to the coast is found to suffer from chloride and saline hazard. Increase in isochlore is observed from the coast up to the Nyeyveli lingnite mine. Such increase in isochlore (Figure 9) indicates the possible migration of chloride ion from the coast up to the Neyveli mine due to depressurization of Neyveli aquifer for safe mining of lignite, which is due south of the study area (Figure 9). Chloride clusters in the south central part of the study area from chloridization of aquifer during the last 48 years may be due to upwelling of connate water from deeper aquifer as a result of depressurization of Neyveli aquifer.

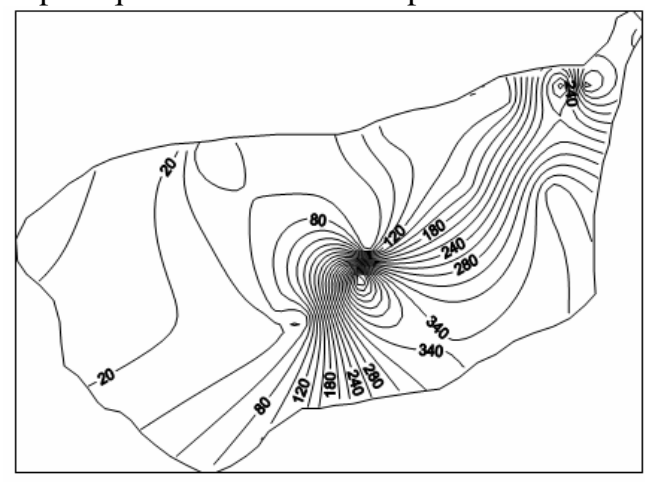

Figure 9. Seasonal variations of $\mathrm{Cl}_{2}$ ions

Nitrate

The largest anthropogenic input of nitrogen into the nitrogen cycle is fertilizers (Panel on Nitrates of the Coordinating Committee for Scientific and Technical Assessments of Environmental Pollutants, 1978). The impact on the nitrogen cycle results in pollution problems such as toxic amounts of nitrate in drinking water, eutrophication in lakes, rivers or coastal waters, all of which posses possible health and environmental consequences.

Globally, nitrogen fixation and the mineralization of organic nitrogen by biological processes produce the largest amount of inorganic nitrogen, usually in the form of nitrate. However, on a local scale, nitrogen inputs from agricultural activities in the form of fertilizers usually exceed those of natural sources. When this occurs, there could be an excessive amount of nitrogen that is not utilized by the plants. This excess amount of nitrogen is usually leached down into the soil by irrigation water or precipitation and has the potential to seriously pollute groundwater and eventually surface waters. Nitrogen is originally fixed from the atmosphere and then mineralized by soil bacteria into ammonium. Under aerobic conditions, nitrogen is finally converted into nitrate by nitrifying bacteria ${ }^{25}$.

Another activity that generates nitrogen input and hence, has the potential to degrade water quality is waste material from livestock, such as cattle, swine and poultry. The forms of nitrogen that livestock produce are usually urea or uric acid. There are four possible fates for this nitrogen once it reaches the soil surface: 1) it may accumulate in the soil; 2) be leached 
down to the subsoil as ammonium; 3) be denitrified; or 4) be lost as volatiles into the atmosphere ${ }^{26}$. All of this surplus nitrogen may seriously affect water quality and air quality.

When more nitrate accumulates in the soil than the plants can use, water from irrigation and precipitation can carry it down through the soil in a process known as 'leaching'. Most of the excess nitrate eventually finds its way to the groundwater. Though nitrate is non-toxic to humans, when nitrate enters the body, bacteria inside the stomach will convert nitrate to nitrite. Infants are at high risk, as an infant's stomach provides an excellent condition for bacteria to convert the nitrate into nitrite. Once the nitrite is formed, it would be absorbed by the intestines and enters the circulatory system, eventually forming a complex with the hemoglobin, whereby the nitrite oxidizes the iron of the hemoglobin to the ferric state $(+3)$, changing it to methemoglobin. Since methemoglobin cannot carry oxygen and the reverse reaction is much slower, the infant would have oxygen starvation which results in a bluish discoloration of the body.

Another serious health problem that can arise from nitrate pollution is stomach cancer. As nitrate it is not toxic; however, nitrite produced from nitrate could pose serious health hazard. Studies have shown that nitrite produced from nitrate could react in the stomach with an organic compound that comes from the breakdown of meat called secondary amine. Result of these two combined forms what is known as an $N$-nitroso compound. It is the $N$-nitroso compound that is able to alter certain components of DNA, leading to cancer ${ }^{27}$.

Nitrate concentration groundwater samples range from $0.4 \mathrm{mg} / \mathrm{L}$ to $64 \mathrm{mg} / \mathrm{L}$. As most of the study area in the northern part is intensively irrigated, fertilizers used for agriculture may be the source for the elevated concentration of nitrate in a few locations in the north. Spatial variation of nitrate in groundwater in the basin is (Figure 10) shows the cluster of nitrate in and around the village Perperiyankuppam.

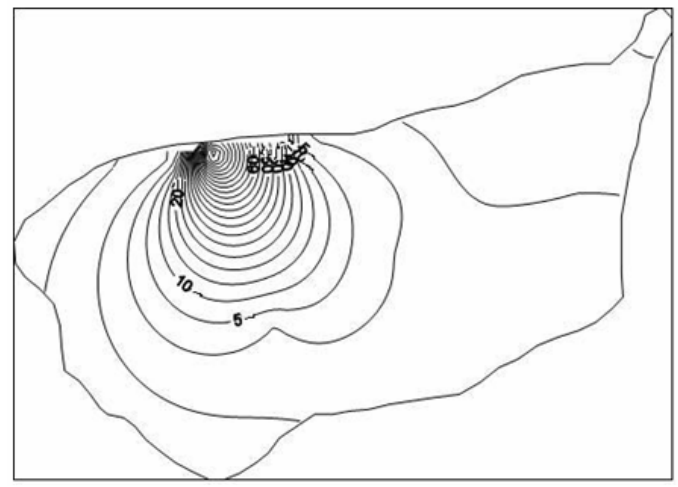

Figure 10. Seasonal variations of $\mathrm{NO}_{3}$ ions

\section{Conclusion}

The major conclusions derived from this study are as follows. The EC value ranges from 160 to $2,580 \mu \mathrm{S} / \mathrm{cm}$ in groundwater samples. The highest value of $2,580 \mu \mathrm{S} / \mathrm{cm}$ was recorded in wells near the coast. $\mathrm{pH}$ value ranges from 7.2 to 8.6. Central and southern part of the study area has high $\mathrm{pH}$ values, which represents the alkaline nature of groundwater.

In south eastern part of the study area alkali values are slightly higher but it is within WHO's tolerable limits. The spatial distribution of chloride concentration shows that Meenatchipettai, Vazhisothani palayam and Allapakkam represents maximum $\mathrm{Cl}_{2}$ concentration respectively of 527, 320 and $374 \mathrm{ppm}$, which is above ISI drinking standards of 250 ppm. Increase in isochlore is observed from the coast up to the Neyveli Lignite mine. 
Such increase in isochlore indicates the possible migration of chloride ion from the coast up to the Neyveli mine due to depressurization of Neyveli aquifer.

Nitrate concentration of groundwater samples ranges from $0.4 \mathrm{mg} / \mathrm{L} \mathrm{to} 64 \mathrm{mg} / \mathrm{L}$. As most of the study area is intensively irrigated, fertilizers used for agriculture may be the cause for increase in concentration of nitrates in a few locations. Northern and southern parts of the study area represent minimum amount of hardness to neutralize acids; hence the above part is categorized under 'poor zone' 'Moderate zone' is found to occur in northwest, southwest and in central parts of the study area as concentration is $<250 \mathrm{ppm}$.

\section{Acknowledgment}

Authors are grateful to UGC with vide Lr.No. F.No.32 - 334106 (SR) dt. 17.05.07 \& 02.08.07 for funding Major Research project "HYCH - MAP" to carry out the above work and deeply indebted to their institution for providing infrastructure facilities. They are also thankful to Chief Engineer, PWD (Groundwater) Chennai for sparring necessary data related to project.

\section{References}

1. Dalton M G and Upchurch S B, Ground Water Res., 1978, 10, 228-233.

2. $\quad$ Bakac M, Environ Geochem Health, 2000, 22(2), 93-111.

3. Dawdy D R and Feth J H, Water Resour Res., 1967, 3:505-510.

4. Jayakumar R and Siraz L, Environ Geol., 1997, 31, 174-177.

5. Lawrence F W and Upchurch S B, American Water Resources Association, USA, 1976, 199-214.

6. Lawrence F W and Upchurch S B, Groundwater, 1983, 20, 680-687.

7. Olmez L J W B and Villaume J F, Water Res., 1994, 28, 1095-1101.

8. Razack M and Dazy J, J Hydrol., 1990, 114:371-393.

9. Subbarao C, Subbarao N V, Chandu S N, Environ Geol, 1996, 28, 175-180.

10. Burrough P A, McDonnell R A, Oxford University Press, Oxford, 1998, 333.

11. Kamaraju M V V, Groundwater, 1997, 34(2), 318-334.

12. Srivastava P K, Bhattacharya A K, Photonirvachak- J Indian Soc Remote Sens., 2000, 28(2), 129-140.

13. Stewart B A, Environ Sci Technol., 1970, 4, 579-582.

14. Chaudhary B S, Kumar M, Roy A K, Ruhal D S, International Archives of Photogrammetry and Remote Sensing, 31, B-6, Vienna, Austria., 1996, 18-23.

15. Sanjay Kumar Goyal, Chaudhary B S, Omvir Singh, Sethi G K and Praveen K. Thakur, Environ Earth Sci., 2010, DOI 10.1007/s12665-010-0472-z.

16. Anbazhagan S and Nair A M, J Environ Geol., 2004, 45(6), 753-761.

17. Balasundar N K, Geol Soc India Mem., 1968, 2, 256-262.

18. Selvaraj K and Ramasamy S, J Geol Soc India, 1998, 51, 803-812.

19. APHA Standard Methods for the Examination of water and wastewater, American Public Health Association, Washington, DC 20036, $19^{\text {th }}$ Edn., 1995.

20. Richards L A, US Department of Agriculture, Hand Book, 1954, 60, 160.

21. Stiff, H.A., Jr., J Petroleum Technol., 1951, 3(10),15-17.

22. WHO,Guidelines to Drinking Water Quality,World Health Organisation,Geneva, 1983, 186.

23. Hem J D, USGS, Water Supply Paper, 1985, 2254, 264.

24. Hem J D, USGS, Water Supply Paper, 1473, 1970.

25. Tindall J A, Petrusak R L and McMohan P B, J Hydrol, 1995, 169, 51-94

26. Stewart B A, Environ Sci Technol., 1970, 4, 579-582.

27. Addiscott T M, Whitmore A P and Powlson D S Farming, C A B International Wallingford Oxford United Kingdom, 1991. 


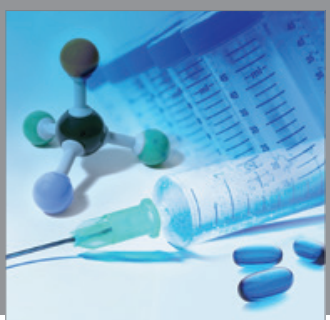

International Journal of

Medicinal Chemistry

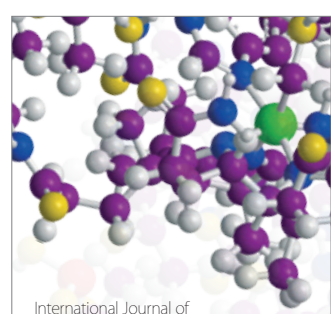

Carbohydrate Chemistry

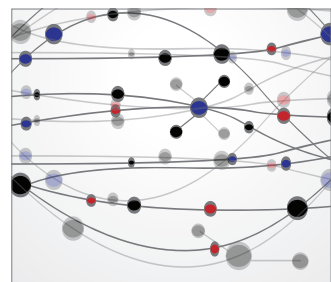

The Scientific World Journal
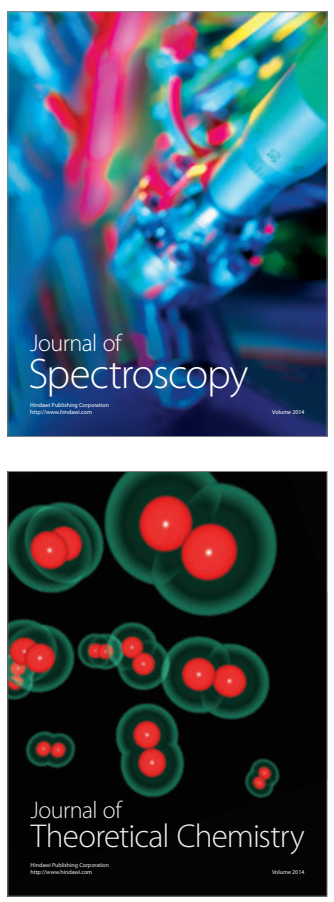
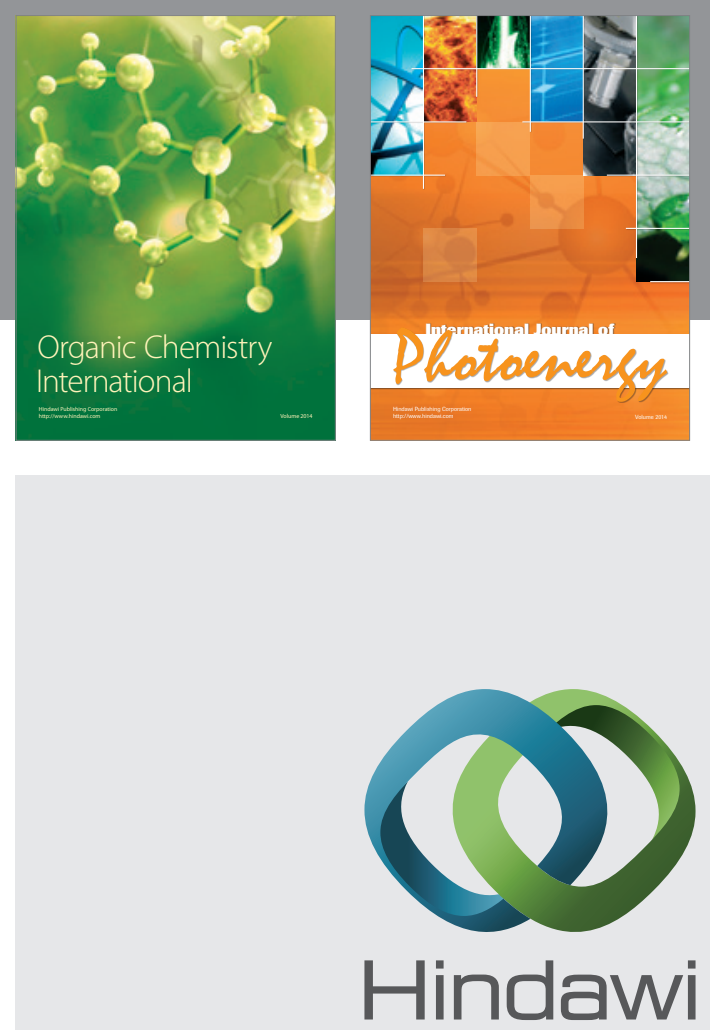

Submit your manuscripts at

http://www.hindawi.com
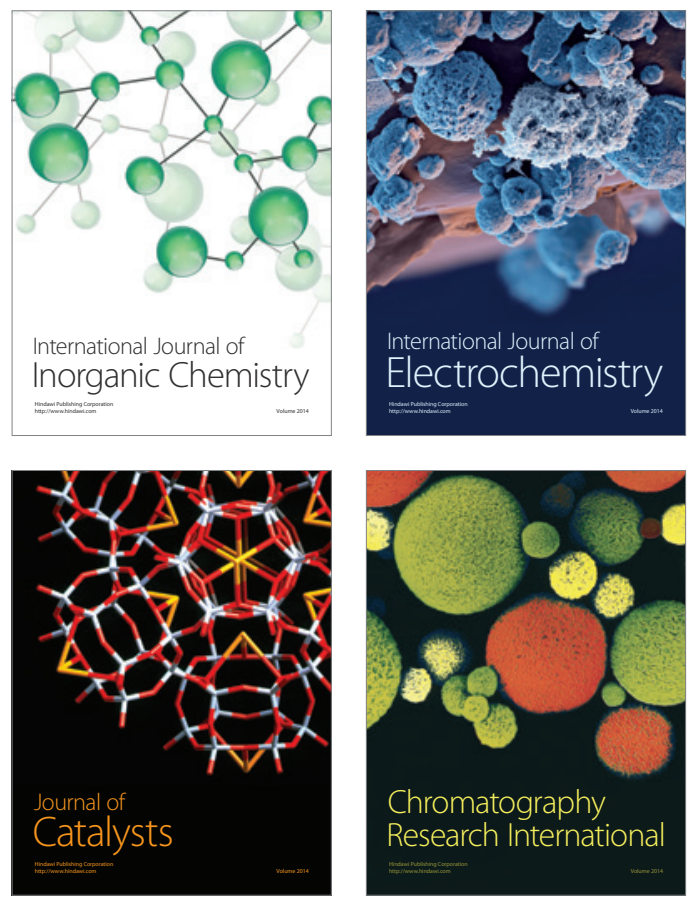
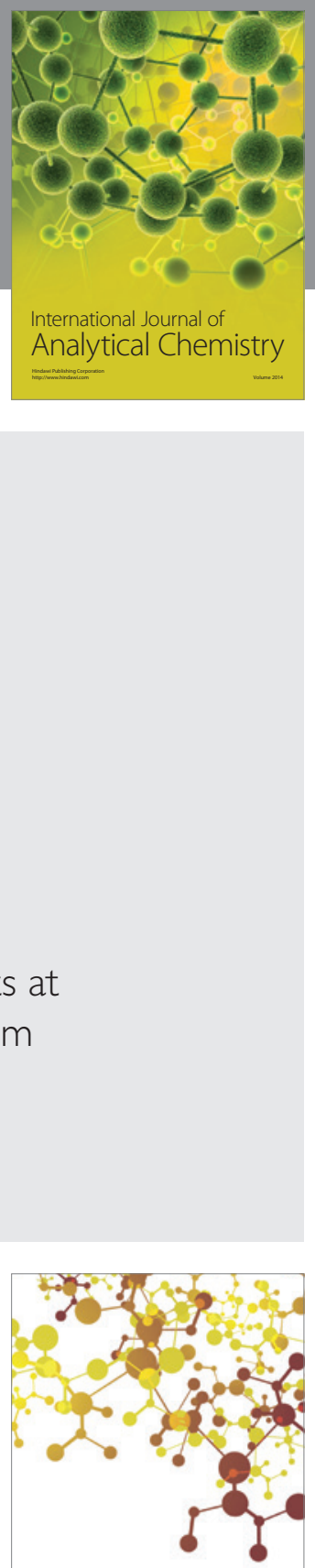

Journal of

Applied Chemistry
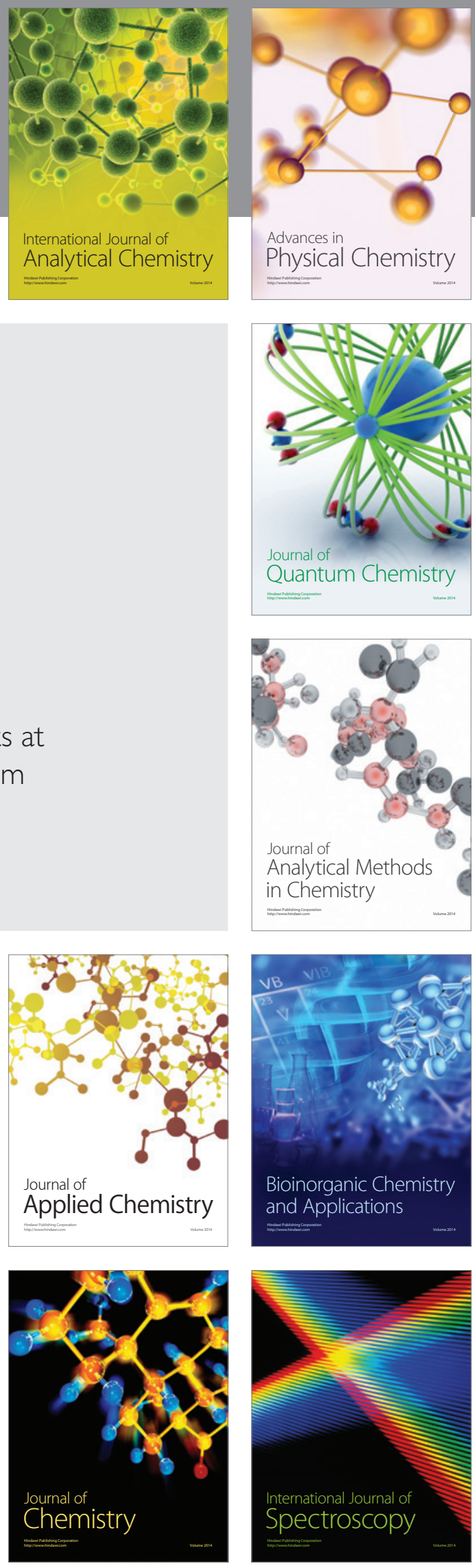